NBER WORKING PAPER SERIES

PENSION FUND INVESTMENT POLICY

Zvi Bodie

Working Paper No. 2752

NATIONAL BUREAU OF ECONOMIC RESEARCH

1050 Massachusetts Avenue

Cambridge, MA 02138

October 1988

This research is part of NBER's research program in Financial Markets and Monetary Economics. This paper was prepared under Department of Labor Contract Number J-9-P-8-0097. Any opinions expressed are those of the author not those of the National Bureau of Economic Research or the Department of
Labor. 
NBER Working Paper \#2752

October 1988

PENSION FUND INVESTMENT POLICY

ABSTRACT

The purpose of this paper is to survey what is known about the investment policy of pension funds. Pension fund investment policy depends critically on the type of plan: defined contribution versus defined benefit. For defined contribution plans investment policy is not much different than it is for an individual deciding how to invest the money in an Individual Retirement Account (IRA). The guiding principle is efficient diversification, that is, achieving the maximum expected return for any given level of risk exposure. The special feature is the fact that investment earnings are not taxed as long as the money is held in the pension fund. This consideration should cause the investor to tilt the asset mix of the pension fund towards the least tax-advantaged securities such as corporate bonds.

For defined benefit plans the practitioner literature seems to advocate immunization strategies to hedge benefits owed to retired employees and portfolio insurance strategies to hedge benefits accruing to active employees. Academic research into the theory of optimal funding and asset allocation rules for corporate defined benefit plans concludes that if their objective is shareholder wealth maximization then these plans should pursue andreme policies. For healthy plans, the optimum is full funding and investment exclusively in taxable fixed-income securities. For very underfunded plans, the optimum is minimum funding and investment in the riskiest assets. Empirical research so far has failed to decisively confirm or reject the predictions of this
theory of corporate pension policy.

Recent rule changes adopted by the Financial Accounting standards Board regarding corporate reporting of defined benefit plan assets and liabilities may lead to a significant shift into fixed-income securities. The recent introduction of price-levelindexed securities in U.S. financial markets may lead to significant changes in pension fund asset allocation. By giving plan sponsors a simple way to hedge inflation risk, these securities make it possible to offer plan participants inflation protection both before and after retirement.

Zvi Bodie

School of Management

Boston University

Boston, MA 02215 


\section{PENSION FUND INVESTMENT POLICY}

zvi Bodie

October 1988

CONIPINTS

page

1. Introduction . . . . . . . . . . . . . . 1

2. Defined Contribution versus Defined Benefit plans 1

2.1 Alternative Perspectives on DB Plans. . . . . 3

2.2 Investment StrategY in DB Pension Plans. . . 4

2.3 The Black-Dewhurst Proposal . . . . . . . 7

3. Research on Corporate Pension Policy . . . . . . 12

3.1 Theory of Corporate Pension Plan Funding and

Asset Allocation Policy . . . . . . . . 12

3.2 Empirical studies . . . . . . . . . . 15

4. Hedging Against Inflation. . . . . . . . . . 17

5. Summary and conclusions . . . . . . . . . . 23

6. References . . . . . . . . . . . . . . 25 


\section{Introduction}

The purpose of this paper is to explore the investment policy of pension funds. In the U.S. today, assets of pension plans amount to almost $\$ 1.8$ trillion, representing the largest single pool of investable funds. An understanding of the principles and practices of pension fund investment management is critical for plan sponsors, for their professional money managers, and for the government officials charged with regulating and/or insuring pension plans.

The paper addresses several questions:

- What are the unique features of pension plans that might cause them to adopt investment policies that differ from those of other investors?

- What does academic research tell us about the theory and practice of pension fund investment policy?

- What are the likely future trends in pension plan asset allocation?

2. Defined Contribution versus Defined Benefit Plans Although employer pension programs vary in design, usually they are classified into two broad types: defined contribution (DC) and defined benefit (DB). These two categories are distinguished in the law under the Employee Retirement Income Security Act (ERISA).

The DC arrangement is conceptually the simpler of the two. Under a DC plan, each employee has an account into which the employer and the employee (in a contributory plan) make regular 
contributions. Benefit levels depend on the total contributions and investment earnings of the accumulation in the account. Defined contribution plans are in effect tax-deferred savings accounts held in trust for the employees.

Contributions usually are specified as a predetermined fraction of salary, although that fraction need not be constant over the course of a career. Contributions from both parties are tax-deductible, and investment income accrues tax-free. At retirement, the employee typically receives an annuity whose size depends on the accumulated value of the funds in the retirement account.

Often the employee has some choice as to how the account is to be invested. In principle, contributions may be invested in any security, although in practice most plans limit investment options to various bond, stock, and money market funds. The employee bears all the investment risk; the retirement account is by definition fully funded, and the firm has no obligation beyond making its periodic contribution.

For defined contribution plans investment policy is not much different than it is for an individual deciding how to invest the money in an IRA. The guiding principle is efficient diversification, that is, achieving the maximum expected return for any given level of risk exposure. The special feature is the fact that investment earnings are not taxed as long as the money is held in the pension fund. This consideration should cause the investor to tilt the asset mix of the pension fund towards the 
least tax-advantaged securities such as corporate bonds.

In a DB plan, the employee's pension benefit entitlement is determined by a formula that takes into account years of service for the employer and, in most cases, wages or salary. Many defined benefit formulas also take into account the social Security benefit to which an employee is entitled. These are called "integrated" plans.

In a typical DB plan, the employee might receive retirement income equal to 18 of final salary times the number of years of service. Thus, an employee retiring after 40 years of service with a final salary of $\$ 15,000$ per year would receive a retirement benefit of $40 \%$ of $\$ 15,000$, or $\$ 6,000$ per year.

The annuity promised to the employee is the employer's liability. The present value of this liability represents the amount of money that the employer must set aside today in order to fund the deferred annuity that commences upon the employee's retirement.

\subsection{Alternative Perspectives on DB Plans.}

Defined benefit pension funds are pools of assets that serve as collateral for the firm's pension liabilities. Traditionally, these funds have been viewed as separate from the corporation. Funding and asset allocation decisions are supposed to be made in the best interests of the beneficiaries, regardless of the financial condition of the sponsoring corporation.

Beneficiaries presumably want corporate pension plans to be as well-funded as possible. Their preferences with regard to 
asset allocation policy, however, are less clear. If beneficiaries are not entitled to any windfall gains-- if the defined benefit liabilities were really fixed in nominal terms -rationally they would prefer that the funds be invested in the least risky assets. If beneficiaries had a claim on surplus assets, though, the optimal asset allocation in principle could include virtually any mix of stocks and bonds.

Another way to view the pension fund investment decision is as an integral part of overall corporate financial policy. Seen from this perspective, defined benefit liabilities are part and parcel of the firm's other fixed financial liabilities, and pension assets are part of the firm's assets. From this point of view, any plan surplus or deficit belongs to the firm's shareholders. The firm thus manages an extended balance sheet, which includes both its normal assets and liabilities and its pension assets and liabilities, in the best interests of shareholders.

2.2 Investment strategy in DB Pension Plans.

The practitioner literature seems to view a firm's pension liabilities as divided into two parts - retired and active. Benefits owed to retired participants are nominal, and benefits accruing to active participants are real. The nominal benefits can be immunized by investing in fixed-income securities with the same duration or even exactly the same pattern of cash flows as the pension annuities.

Accruing benefits, on the other hand, call for a very 
different investment policy, whose essence can be summarized as follows. In estimating the liabilities to active participants, the firm's actuaries make an "actuarial interest rate" assumption that becomes the target rate for the pension asset portfolio. Managers of the pension fund should view the possibility of receiving a rate of return below the actuarial assumption as having a greater negative weight than the positive weight associated with a return above the actuarial assumption. This factor will affect the asset allocation decision.

Portfolio insurance is an investment strategy that developed in response to this view. It calls for maintaining an asset portfolio with a truncated and positively skewed probability distribution of returns. The probability of getting returns below the actuarial rate is zero, while the probabilities of returns above the actuarial rate are positive.

Portfolio insurance can be accomplished in a number of ways. The most direct method is to invest in common stocks and buy protective puts on them, which eliminates downside risk while maintaining upside potential. Of course, the guaranteed minimum return on such a policy will always be lower than the risk-free rate. Another method is to invest in T-bills and buy call options.

The third way of providing portfolio insurance is to pursue a dynamic hedging strategy with stocks and T-bills. The strategy involves continuous portfolio revision to replicate the payoff structure of the two previous strategies. It involves selling 
stocks when their price falls and buying them when their price rises. 1

While it reduces downside risk, the adoption of portfolio insurance principles should lead to a lower average rate of return than on uninsured portfolios. Indeed, if pension funds have been insuring to any significant extent by pursuing even limited dynamic hedging strategies, one should expect to find that their average performance falls short of the average performance of conventionally managed portfolios.

This may help to explain the results reported in a recent study by Berkowitz and Logue (1986). They found that the average risk-adjusted performance of ERISA plans from 1968 to 1983 was lower than returns experienced by other diversified portfolios in U.S. financial markets. Reallocation between stocks, bonds and cash equivalents had a significant deleterious effect on the portfolio performance of ERISA plans. It should be noted that the risk-adjusted performance measure used by Berkowitz and Logue is not really appropriate for measuring the performance of insured portfolios because it ignores the positive skewness of the distribution of returns that is the main objective of portfolio insurance strategies.

Recent changes in accounting rules may have a profound effect on the investment policies of pension funds, reinforcing the trend toward the use of immunization and portfolio insurance

\footnotetext{
${ }^{2}$ For a more complete discussion of dynamic hedging see Chapter 20 of Bodie, Kane, and Marcus (1988).
} 
strategies. According to Rule 87 of the Financial Accounting standards Board (FASB), corporations must report their unfunded pension liability on the corporate balance sheet. Previously they reported this liability only in the footnotes to their financial statements. Furthermore, the interest rate they use in computing the present value of accrued benefits must be the current rate on long term bonds. ${ }^{2}$ The result is that fluctuations in long term interest rates will produce large swings in reported pension liabilities that could, in the absence of offsetting actions by the corporation, play havoc with the firm's debt ratios.

Generally, security analysts and other observers of corporate financial behavior expect that, in order to offset this effect of FASB 87, corporations are likely to hedge the impact of interest rate fluctuations on reported pension liabilities by a strategy of duration matching, which will minimize the net effect on unfunded pension liabilities. ${ }^{3}$ The impact on pension fund asset allocation could be profound. There may be a significant shift away from equities toward fixed-income securities.

\subsection{The Black-Dewhurst Proposal}

In 1981 Fischer Black and Moray Dewhurst created a stir among pension plan finance specialists with a proposal that

${ }^{2}$ Corporations retain the right to use a different interest rate assumption in their actuarial calculations for funding decisions than they use for financial reporting purposes.

${ }^{3}$ See Leibowitz and Henricksson (1988) for a discussion of the investment implications of focussing on the pension surplus. 
carries to a logical extreme the notion that a pension plan is a way to shelter investment income from corporate income taxes. 4 That is, in order to maximize the value of a firm to its shareholders, a firm should fully fund its pension plan and invest the entire amount in bonds.

Black and Dewhurst propose that the firm arbitrage taxes by substituting bonds for stocks in the pension fund. The simple form of the proposal consists of four operations carried out at the same time:

1. Sell all equities, $\$ \mathrm{X}$, in the pension fund;

2. Purchase on pension account $\$ X$ of bonds of the same risk as the firm's own bonds;

3. Issue new debt in an amount equal to $\$ x$; and

4. Invest $\$ \mathrm{X}$ in equities on corporate account.

The net effect of these operations is that the firm has more debt outstanding owed on corporate account and more bonds owned on pension account. The market value of the firm's own shares should thereby increase by as much as the corporate tax rate times the amount of new debt taken on in the maneuver.

The plan adds value because the firm earns close to the pretax rate of return on the bonds in the fund while paying the after-tax rate on the debt issued to support the procedure. Given that only 20 of the dividends from the common stock are

${ }^{4}$ See Black, Fischer and M.P. Dewhurst, "A New Investment Strategy for Pension Funds," Journal of Portfolio Management,
summer 1981 . 
taxable, and that the tax on the capital gains can be deferred indefinitely by not selling appreciated stock, the effective tax rate on the equities held on corporate account will be very low. Thus, the after-tax return on the equities will not be reduced significantly if they are switched from pension account to corporate account. If all value accrues to the firm's shareholders, if the effective corporate tax rate on equities is zero, and if the stocks held on corporate account are equivalent to the stocks previously held by the pension fund, the gain to shareholders has a present value of $\$ T X$ where $T$ is the firm's marginal corporate income tax rate.

An example will clarify this proposal. The Hi-Tek Corporation is a relatively new company with a young work force and a fully-funded defined benefit pension plan. Hi-Tek's total corporate assets are worth $\$ 50$ million, and its capital structure is $20 \%$ debt and $80 \%$ equity. Its pension assets consist entirely of a well-diversified portfolio of common stocks indexed to the S\&P 500 and worth $\$ 10$ million. The present value of its pension liabilities is $\$ 10$ million. Table la shows the corporate balance sheet and Table $1 \mathrm{~b}$ the pension fund's balance sheet.

Hi-Tek's treasurer, who is in charge of the pension fund, reads the Black-Dewhurst article and decides to implement the proposal. The pension fund sells its entire $\$ 10$ million stock portfolio to the corporation and invests the proceeds in corporate bonds issued by other high tech companies. The corporation pays for the stock by issuing $\$ 10$ million of new 
bonds. The resulting balance sheets appear in Table 2 .

According to Black and Dewhurst, the result of these transactions should be an increase in the market value of owners' equity of as much as $\$ 10$ million times the corporate tax rate, currently $34 \%$. In other words, the market value of the outstanding shares of Hi-Tek's common stock should increase by $\$ 3.4$ million. 5

To see why, let $r$ be the interest rate on the debt. As a result of the four operations above, the company now earns $r \mathbf{x} \$ 10$ million per year in interest on the bonds it bought on pension account while paying from its after-tax cash flow $(1-T) r$ $x \$ 10$ million per year on the debt it issued on corporate account. The net cash flow to the firm will be $.34 \mathrm{r} \times \$ 10$ million per year, the tax saving on the interest. The present value of this saving in perpetuity is $\$_{3.4}$ million:

$$
\frac{(.34 \mathrm{r} \times \$ 10 \text { million })}{r}=\$ 3.4 \text { million }
$$

Note that even though Hi-Tek's debt ratio has increased from .2 to .3 , the overall risk of the firm has not changed. If we accept the theory that the pension fund assets and liabilities belong to the shareholders, the risk of the assets does not change when the $\$ 10$ million of stock in the pension fund is, in effect, transferred to corporate account.

${ }^{5}$ If the corporate tax rate on equities is greater than zero, the gain in shareholders' equity will be smaller. 
Table 1. H1-Tek Corporation Balance Sheets Before Black-Dewhurst Maneuver

a. Corporate Balance Sheet ( $\$$ million)

Assets

Current Assets

Property Plant \& Equipment $\frac{48}{50}$ Total

b. Pension Fund Balance Sheet ( $\$$ million)

Liabilities and Owners' Equity

\begin{tabular}{lllr} 
& & \multicolumn{2}{c}{ Liabilities and Fund Balance } \\
\cline { 3 - 4 } & $\$ 10$ & PV of Accrued Benefits & $\$ 10$ \\
Equits & Fund Balance
\end{tabular}

Table 2. Hi-Tek Corp. Balance Sheets After Black-Dewhurst Maneuver
a. Corporate Balance Sheet ( $\$$ million)

Assets

Current Assets

Property Plant \& Equipment

stocks

Total
Liabilities and Owners' Equity

Debt

O.E.

$\$ 20$

48

$\$ \frac{10}{\$ 60}$
$\$ 10$

40 
This plan implies that the company should increase its contributions to the pension plan up to the limits allowed by the IRS. This is because for every dollar of assets added to the pension fund, invested in bonds, and supported by issuing new bonds, the tax saving increases by $\mathrm{TT}$ per year, and the PV of shareholders' equity increases by $\$ T$. Thus if $T$ is .34 , shareholders' equity rises by $\$ .34$ for every dollar added to pension assets or for every dollar switched out of stocks into bonds.

3. Research on Corporate Pension Policy

The financial aspects of corporate pension plans have increasingly attracted the attention of academics. Much of this attention has focused on theoretical analysis of the tax and incentive aspects of corporate pensions. Models of optimal capital structure have yielded testable implications for plan funding and investment strategy (Black 1980; Tepper 1981), while advances in option pricing theory have highlighted the perverse incentives created by Pension Benefit Guarantee Corporation (PBGC) insurance (Sharpe 1976; Treynor 1977).

As yet, however, empirical work has failed to decisively confirm or reject these effects. Below we provide a brief overview of the relevant theory and of previous empirical work designed to test that theory.

3.1 Theory of Corporate Pension Plan Funding and Asset Allocation Policy

The academic literature more and more views pension 
decisions as an integral part of overall corporate financial policy. From this perspective, employee benefits accrued under a defined benefit pension plan are a long-term liability of the firm. Pension assets, while collateral for these liabilities, are assets of the firm in that the surplus/deficit belongs to the firm's shareholders. This integrated perspective requires managing the firm's extended balance sheet, including both its conventional assets and liabilities and its pension assets and liabilities, in the best interests of the shareholders.

Such a corporate financial perspective explicitly ignores the interests of the beneficiaries, in part because their defined benefits are insured by the PBGC. According to this view, if the beneficiaries are protected by the government, corporate pension decisions become what amounts to a game between the corporation and various government agencies and interests, a game that can be and should be thought of as an integral part of corporate financial policy.

The first pension decision of interest is the level-offunding decision: are there incentives for the firm to over- or underfund its pension liability? The tax effects are the first, and for most companies, the most important, part of this game. In closely related papers, Black (1980) and Tepper (1981) argue that the unique feature of pension funds from this integrated perspective is their role as a tax shelter. Because firms can effectively earn a pretax rate of return on any assets held in the pension fund and pass these returns through to shareholders, 
much as if the pension fund were an IRA or Keogh plan, the comparative advantage of a pension fund lies in its ability to be invested in the most heavily taxed assets. As Black and Dewhurst have demonstrated, the potential increase in the value of shareholders' equity resulting from a tax-sheltering strategy is substantial.

This means that pension funds should be invested entirely in taxable bonds, instead of common stock, real estate, or other assets that in effect are taxed at lower marginal tax rates for most shareholders, and that the corporation should fund its pension plan to the maximum extent allowed by the IRS so as to maximize the value of this tax shelter to shareholders. The tax effects of pensions should therefore induce corporations to follow extreme policies. Fully funded or overfunded pension plans should place their assets entirely in taxable bonds.

A second effect that may influence the level of funding, the "pension put" effect, is associated with the work of sharpe (1976), Treynor (1977), and Harrison and Sharpe (1983). Briefly, the PBGC's insurance of pension benefits in effect gives the firm a put option. As with any option, the value of this put increases with the risk of the underlying asset. Thus, as long as the PBGC neither regulates pension fund risk nor accelerates its own claim at the first sign of financial distress, the firm has an incentive to undermine the PBGC's claim. It can do so and maximize the value of its put option by funding its pension plan only to the minimum permissible extent and investing the pension 
assets in the riskiest possible securities. This of course is the exact opposite policy from the decision suggested by the tax effects described above.

These two theories point to specific firm characteristics as the key determinants of corporate pension policies: profitability, risk (including leverage), and tax-paying status. Two major studies have explored the empirical relationship between the financial characteristics of corporations and their asset allocation policies. They are described in detail below. 3.2 Empirical studies

Friedman (1983) was the first to test empirically for the impact of firm financial characteristics on pension policy. Integrating data from the standard \& Poor's Compustat file and Form 5500 data for 1977 , he examined the relationship between asset allocation and measures of business risk and leverage. He estimated a number of relationships of the following form: the dependent variable was some aspect of the pension decision such as unfunded liabilities or the proportion of pension assets invested in bonds; independent variables included measures of conventional financing, such as ordinary balance sheet liabilities, plus one other control variable such as firm profitability, risk, and tax-paying status.

Friedman concluded that pension decisions are indeed related to other aspects of the corporate financing decision. He found that unfunded liabilities and the proportion of pension assets invested in bonds are both positively related to ordinary balance 
sheet liabilities. He also found that a reverse relationship holds, with balance sheet leverage depending positively on unfunded pension liabilities, regardless of the control variable used - a "risk-offsetting effect."

Results with tests of individual variables such as taxpaying status, however, do not favor any strong conclusion (and often change sign with specification), thus raising rather than resolving questions. This may be the result of bias induced by firm-to-firm variability in actuarial assumptions used in calculating reported liabilities. That is, reported liabilities may have differed across firms in the sample solely as a result of discount rate assumptions.

Bodie, Light, Morck, and Taggart (1987) demonstrated that reported liabilities were systematically biased because of the way firms chose the discount rates that they used in calculating the present value of accrued benefits. They examined the asset allocation choices for 215 firms using data collected in 1980 and estimated reduced form relationships between pension decisions and the firm's tax-paying status, profitability, and risk. Their data come from FASB 36 filings for 1980, which include interest rate assumptions, so they were able to adjust reported liabilities roughly to a common rate. In this initial adjustment, they found that the reporting of pension fund liabilities was systematically linked to company profitability through the choice of a discount rate. More profitable firms tended to choose lower discount rates and thus to report greater 
pension liabilities.

The first pension decision examined in Bodie et al. was the extent of funding, measured by pension assets as a fraction of vested pension liabilities. There was strong evidence that firm profitability is positively related to funding, but no statistically significant relationship between funding and risk or tax-paying characteristics. Some evidence of the pension put effect was found when the sample was split by riskiness of the firm.

The study also examined asset allocation. The proportion of assets held in fixed-income securities was related to the same firm characteristics listed above. A significant fraction of firms invested their pension assets entirely in fixed-income securities, and the proportion of assets allocated to fixedincome securities was positively related to the level of funding. 4. Hedging Against Inflation.

As we pointed out earlier, DB pension funds often view their accruing pension liabilities to active employees as fixed in real as opposed to nominal terms. In that case, a portfolio is efficient if it offers the minimum variance of real rate of return for any given mean real rate of return.

Most textbook expositions of portfolio selection theory, however, and indeed most real world applications of that theory, are cast in nominal terms. Typically, Treasury bills are taken as the risk-free asset, and the optimal combination of risky assets is constructed on the basis of the covariance matrix of 
nominal returns. All efficient portfolios are combinations of cash and the optimal nominally risky portfolio.

Since January 1988, however, U.S. investors have had available to them the possibility of investing in virtually riskfree securities linked to the U.S. consumer price level. The new securities were issued by the Franklin Savings Association of ottawa, Kansas in two different forms. The first is certificates of deposit, called Inflation-Plus CDs, insured by the Federal Savings and Loan Insurance corporation (FSLIC), and paying an interest rate tied to the Bureau of Labor Statistics Consumer Price Index (CPI). Interest is paid monthly and is equal to a stated real rate plus the proportional increase in the CPI during the previous month. As of this writing (September 1988), the real rate ranges from $3 \%$ per year for a one-year maturity $C D$ to 3.38 per year for a ten-year maturity.

The second form is twenty-year noncallable collateralized bonds, called Real Yield Securities, or REALs. These offer a floating coupon rate of 38 per year plus the previous year's proportional change in the CPI, adjusted and payable quarterly. A recent issue of similar bonds includes a put option.

Two other financial institutions have recently followed the lead of Franklin Savings. 6 It seems as if we have reached a milestone in the history of the financial markets in the U.S..

${ }^{6}$ In August 1988 Anchor Savings Bank became the second U.S. institution to issue REALs, and in september 1988 JHM Acceptance Corporation issued modified index-linked bonds subject to a nominal interest rate cap of $14 \%$ per annum. 
For many years prominent economists from all ends of the ideological spectrum have been arguing in favor of the U.S. Treasury's issuing such securities, and scholars have speculated about why private markets for them have not hitherto developed. 7 The existence of CPI-linked bonds makes possible inflationprotected retirement annuities. Retired people have long been considered the most vulnerable to inflation risk, but proposals for private market solutions to their problem have been stymied by the lack of a real risk-free asset. 8

Bodie (1980), for example, proposed the idea of a variable annuity offering at least limited protection against inflation risk, but his proposal lacked appeal primarily because of the low mean real rate of return available on money market instruments (between 0 and 18 per year), the best available inflation hedge at that time. 9 with the availability of virtually riskfree securities offering real rates in excess of 36 per year, the situation is markedly different. Pension funds and other providers of retirement benefits, who currently offer only nominal annuities, could also offer attractive real annuity

${ }^{7}$ See, for example, the analysis in Fischer (1986).

${ }^{8}$ Feldstein (1983) and summers (1983) have both argued that the elderly may in fact already be over-indexed because of their claims to Social security benefits and their ownership of real estate.

${ }^{9}$ Bodie suggested improving the inflation protection afforded by money market instruments by hedging them against unanticipated inflation with a very small position in a well-diversified portfolio of commodity futures contracts. 
options to retirees.

To illustrate how such a real annuity option might work, assume that you are an individual who at retirement is entitled to a benefit with a present value of $\$ 100,000$. Your retirement plan currently offers you a conventional nominal annuity computed on the assumption of a nominal interest rate of $8 \%$ per year and a life expectancy of 15 years. Assuming the first payment is to be received immediately, the annual benefit is $\$ 10,818$. The plan hedges its liability to you by investing in risk-free nominal bonds paying a nominal rate of $8 z$ per year.

From your perspective the real value of this stream of benefits is uncertain. Consider the purchasing power of the final benefit payment to be received 14 years from now. If the rate of inflation turns out to be $5 \%$ per year, the real value of the final benefit will be $\$ 5,464$, about half the value of the first payment. If the rate of inflation turns out to be $10 \%$ per year, the real value of the final payment drops to $\$ 2,849$.

Contrast this with a hypothetical real annuity. since your plan can now invest your $\$ 100,000$ to earn a real risk-free rate of 38 per year it could offer you a real annuity computed on the assumption of $3 \%$ per year. Your annual benefit would be $\$ 8,133$ guaranteed in real terms. While the initial payment is lower than under the nominal option, the real value of the benefit is insured against inflation.

It is important to realize that the real annuity need not start at a lower value than the conventional nominal annuity. 
Bodie and Pesando (1983) have shown how real annuities can be designed with the same starting value as conventional nominal annuities. Such a real annuity would have to have a downward tilt to the benefit stream, just like the expected real value of the benefit stream from the nominal annuity. The essential difference would then be that the real annuity would be insured against inflation while the nominal annuity would not.

The idea of indexing retirement annuities after retirement is only one aspect of inflation-proofing private pension plans. Another is the indexation of benefit accruals under private defined benefit (DB) plans. The accrual patterns and real benefit streams under virtually all private DB plans in the U.S. are extremely sensitive to inflation. Inflation reduces the real value of $D B$ entitlements because pension benefits are fixed in nominal terms once an employee stops working for the plan sponsor or once the sponsor terminates the plan. This reduces the value of accrued benefits to all participating employees, but it especially affects those who switch employers during their working careers.

For example, suppose you are 45 years old and have worked for the same employer for 20 years. Assume that your DB plan promises 18 of final salary per year of service; that your most recent salary was $\$ 50,000$; that normal retirement age is 65 , and that your life expectancy is age 80 . Your claim on the pension fund is a deferred annuity of $\$ 10,000$ per year starting at age 65 and lasting for 15 years. 
If you leave your current employer, what do you have? Since the benefit is not indexed to any wage or price level the way social security is, the benefit will be losing real value as the price level goes up. Assuming inflation of $5 q$ per year, the value of $\$ 1$ will have fallen to $\$ .38$ by the time you retire, so your first year's benefit of $\$ 10,000$ will have a real value of only $\$ 3,800$, and that value will continue to fall each year as inflation continues. If, however, you stay with your employer, and your salary increases at the rate of inflation, and your employer indexes your benefit to the cost of living after retirement, then you will have an annuity worth $\$ 10,000$ of today's purchasing power per year for life.

Looking at the situation in terms of present values and assuming a nominal discount rate of $8 \%$ per year and a real discount rate of $3 z$ per year, your accrued benefit if you switch jobs or if the plan is terminated has a present value of $\$ 18,364$. If you continue, with complete indexation both before and after retirement the accrued benefit has a present value of $\$ 66,097$. One simple alternative to the current system of DB pensions is to offer pension benefits whose value is defined in real terms. This is most readily accomplished by indexing the starting level of benefits either to an index of wages (the way Social security is indexed) or to an index of prices like the CPI even for employees who leave the firm. Similarly, a cost of living provision could be included in the benefit formula after retirement. 
To the extent that pension plans actually were to offer indexed benefits to their employees, pension fund asset allocation could be profoundly affected. A switch to indexed pensions would probably result in hedging strategies involving investment in long-term securities linked to the price level.

5. Summary and conclusions

Pension fund investment policy depends critically on the type of plan: defined contribution versus defined benefit. Both types of plan normally are exempt from taxation, but defined benefit plans have unique features that can lead their sponsors to pursue investment policies that differ radically from those of defined contribution plans.

- For defined contribution plans investment policy is not much different than it is for an individual deciding how to invest the money in an Individual Retirement Account (IRA). The guiding principle is efficient diversification, that is, achieving the maximum expected return for any given level of risk exposure. The special feature is the fact that investment earnings are not taxed as long as the money is held in the pension fund. This consideration should cause the investor to tilt the asset mix of the pension fund towards the least tax-advantaged securities such as corporate bonds.

- For defined benefit plans the practitioner literature seems to advocate immunization strategies to hedge benefits owed to retired employees and portfolio insurance strategies to 
hedge benefits accruing to active employees. Academic research into the theory of optimal funding and asset allocation rules for corporate DB plans concludes that, if their objective is shareholder wealth maximization, these plans should pursue extreme policies. For healthy plans, the optimum is full funding and investment exclusively in taxable fixed-income securities. For very underfunded plans, the optimum is minimum funding and investment in the riskiest assets. Empirical research has so far failed to decisively confirm or reject the predictions of this theory of corporate pension policy.

Recent rule changes adopted by the Financial Accounting standards Board regarding corporate reporting of defined benefit plan assets and liabilities may lead to a significant shift into fixed income securities. The recent introduction of price-level indexed securities in U.S. financial markets may lead to significant changes in pension fund asset allocation. By giving plan sponsors a simple way to hedge inflation risk, these securities make it possible to offer plan participants inflation protection both before and after retirement. 
6. References

1. Berkowitz, Logue and Associates, Inc., "Study of the Investment Performance of ERISA Plans," Prepared for the Office of Pension and Welfare Benefits; Department of Labor, July 21, 1986.

2. Black, Fisher, "The Tax Consequences of Long Run Pension Policy," Financial Analysts Journal, September-October 1980 , pp. 17-23.

3. Black, Fischer and M.P. Dewhurst, "A New Investment strategy for Pension Funds," Journal of Portfolio Management, Summer 1981 .

4. Bodie, Zvi, "An Innovation for Stable Real Retirement Income," The Journal of Portfolio Management, Fall 1980, pp. 5-13.

5. Bodie, Zvi, Jay O. Light, Randall Morck and Robert $\mathrm{H}$. Taggart, Jr., "Corporate Pension Policy: An Empirical Investigation," in Issues in Pension Economics, Bodie, Shoven and Wise, ed., Chicago: University of Chicago Press, 1987 .

6. Bodie, Zvi, Kane, Alex and Marcus, Alan J., Investments, Irwin, Homewood Illinois, 1989.

7. Bulow, Jeremy, "What are Corporate Pension Liabilities," Quarterly Journal of Economics, 97, August 1982.

8. Feldstein, Martin, "Private Pensions as Corporate Debt," in

Ben Friedman, ed., Changing Roles of Debt and Equity in Financing U.S. Capital Formation, University of Chicago Press, 1982 .

9. Friedman, Benjamin M., "Pension Funding, Pension Asset Allocation and Corporate Finance: Evidence from Individual Company Data," in Einancial Aspects of the United States Pension system, Chicago: University of Chicago Press, 1983.

10. Harrison, M.J. and Sharpe, W. F., "Optimal Funding and Asset Allocation Rules for Defined Benefit Pension Plans," Chapter 4 of Bodie and Shoven, eds., Financial Aspects of U.S. Pension Systems, University of Chicago Press, 1983.

11. Leibowitz, Martin L., Henriksson, Roy D., "Portfolio Optimization within a Surplus Framework," Einancial Analysts Journal, Vol. 44, No. 2: March/April 1988. 
12. Sharpe, William F., "Corporate Pension Funding Policy," Journal of Financial Economics, June 1976, pp. 183-193.

13. Tepper, Irwin, "Taxation and Corporate Pension Policy," Journal of Finance, March 1981, pp. 1-13.

14. Treynor, Jack, "The Principles of Corporate Pension Finance," Journal of Finance, May 1977, pp. 627-638. 